Jurnal Kesmas Asclepius

Volume 2, Nomor 2, Desember 2020

e-ISSN: 2684-8287

p-ISSN: 2656-8926

DOI: https://doi.org/10.31539/jka.v2i2.1418

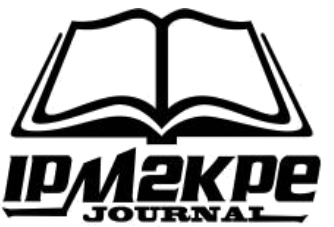

\title{
TOUCH, TALK DAN SKILL PLAY TERHADAP PENURUNAN KECEMASAN ANAK PRE-SCHOOL
}

\author{
Padila $^{1}$, Lussyefrida Yanti ${ }^{2}$, Bintang Agustina Pratiwi ${ }^{3}$, Wulan Angraini ${ }^{4}$, \\ Rengga Depri Admaja ${ }^{5}$ \\ Universitas Muhammadiyah Bengkulu ${ }^{1,2,3,4,5}$ \\ padila@umb.ac.id ${ }^{1}$
}

\begin{abstract}
ABSTRAK
Tujuan penelitian ini untuk mengetahui perbandingan penggunaan Alat Permainan Edukatif (APE) touch and talk dan skill play bermain ular tangga terhadap penurunan tingkat kecemasan anak usia pra sekolah. Metode penelitian ini adalah penelitian kuantitatif dengan rancangan quasy eksperimen two group pretest-posttest design. Hasil penelitian didapatkan pada kelompok Alat Permainan Edukatif (APE) touch and talk sebelum dilakukan intervensi memilki rata-rata skor kecemasan yaitu 31,62 dan setelah diberikan intervensi menjadi 17,31 dengan p-value 0,000, pada kelompok bermain ular tangga memiliki rata-rata skor kecemasan sebelum diberikan intervensi yaitu 31,56 dan setelah diberikan intervensi menjadi 24,38 dengan p-value 0,000. Hasil uji statistik didapatkan p-value $0,001<$ alpha $(0,05)$. Simpulan, ada perbedaan antara kelompok APE touch and talk dan kelompok skill play bermain ular tangga terhadap penurunan tingkat kecemasan anak usia pra sekolah.
\end{abstract}

Kata Kunci: Pra Sekolah, Skill Play, Touch and Talk

\section{ABSTRACT}

The purpose of this study was to determine the comparison of the use of touch and talk Educational Game Tools (APE) and the skill play of playing snakes and ladders to reduce anxiety levels of pre-school age children. This research method is a quantitative study with a quasy experimental design of two groups pretest-posttest design. The results obtained in the Touch and Talk Educational Game Tool (APE) group before the intervention had an average anxiety score of 31.62 and after being given the intervention it was 17.31 with a pvalue of 0.000, the group playing snake and ladder had an average The score of anxiety before being given intervention was 31.56 and after being given the intervention it was 24.38 with a p-value of 0.000. The statistical test results obtained p value 0.001 <alpha (0.05). In conclusion, there is a difference between the APE touch and talk group and the snake and ladder playing skill group to reduce the anxiety level of pre-school children.

Keywords: Pre School, Skill Play, Touch and Talk 


\section{PENDAHULUAN}

Kecemasan merupakan kondisi dimana perasaan yang terjadi dan dirasakan hampir oleh seluruh pasien anak yang masih menjalani perawatan dan mengalami hospitalisasi. Perasaan cemas yang paling banyak dialami oleh anak seperti menangis, ketakutan secara berlebihan baik kepada petugas dan orang yang baru dijumpai. Akibat mendapati stressor secara berlebihan pada anak ketika sedang menjalani masa hospitalisasi mengakibatkan timbulnya dampak negatif sehingga dapat mengganggu terhadap perkembangan anak (Marni \& Ambarwati, 2019).

Survey yang dilakukan lembaga kesehatan dunia (WHO) menyebutkan bahwa di Amerika Serikat sedikitnya terjadi 5 juta angka kejadian pada anak usia pra sekolah yang menjalani hospitalisasi dikarenakan prosedur tindakan bedah dan $50 \%$ diantaranya mengalami kejadian kecemasan dan menyebabkan stress ketika menjalani perawatan. Angka kejadian anak usia pra sekolah yang menjalani hospitalisai di Indonesia menurut Survei Kesehatan Nasional (SUSENAS) pada tahun 2010 menyebutkan bahwa pada daerah perkotaan menurut kelompok usia pra sekolah (3-6 tahun) sebanyak 25,8 \%, pada anak usia sekolah (6-12 tahun) sebanyak 14,91 \%, dan pada usia remaja (13-15 tahun) sebanyak 9,1\%, dapat disimpulkan bahwa angka kejadian anak yang sedang menjalani masa hospitalisasi berada pada anak usia pra sekolah (Apriany et al., 2018).

Anak pada rentang usia pra sekolah adalah suatu individu yang sangat unik dan memiliki ciri dan sifat yang berbeda dengan orang dewasa. Usia pra sekolah dapat digolongkan pada anak yang memiliki usia pada rentang 3 hingga 6 tahun. Pada rentang usia ini anak akan sangat waspada dan berhati-hati terhadap sesuatu hal yang mungkin dianggap akan menyebabkan mereka terluka atau tersakiti. Bahkan salah satu hal yang menyebabkan mereka merasa ketakutan secara berlebih dapat terjadi pada usia ini dikarenakan perasaan takut akan kehilangan sesuatu hal yang dicintai dan terhadap perubahan lingkungan ataupun situasi tempat mereka berada misalnya berada di rumah sakit atau sedang mengalami hospitalisasi (Yanti \& Alfathona, 2019).

Pada usia ini anak akan menganggap bahwa kecemasan akibat sakit yang dialami dapat menimbulkan sesuatu perasaan atau hal yang sangat menakutkan dan dapat menimbulkan perubahan pada lingkungan menjadi sangat tidak menyenangkan. Hal ini yang mendasari perilaku anak seringkali menjadi tidak kooperatif seperti meminta pulang, takut ketika berinteraksi kepada petugas kesehatan yang ada, menangis, atau melakukan tindakan yang agresif seperti menggigit, menendeng, memukul, atau berlari keluar. Hal-hal tersebut membuat anak tidak nyaman dan menolak ketika diberikan tindakan keperawatan (Apriany et al., 2018).

Kecemasan pada anak usia ini tidak dapat dianggap hal yang sepele dan terus dibiarkan, karena pada hal ini akan menyebabkan berdampak buruk pada pemulihaan anak yang sedang menjalani perawatan. Salah satu cara untuk menangani kecemasan dapat dilakukan dengan memberikan terapi berupa aktivitas bermain. Terapi bermain merupakan terapi yang cukup efektif menekan angka kecemasan pada pasien yang menjalani hospitalisasi. Bermain dapat membuat anak terlepas dari ketegangan dan stres yang dialaminya. Salah satu terapi bermain yang sesuai pada anak usia pra sekolah adalah jenis permainan skill play, dimana permainan lebih banyak menggunakan kemampuan motoriknya. Salah satu permainan skill play yang banyak digunakan adalah bermain ular tangga (Colin et al., 2020). 
Berdasarkan penelitian oleh Apriany et al., (2019) kecemasan yang dirasakan anak terjadi ketika berada di rumah sakit dan membutuhkan perawatan untuk mengatasi kecemasannya. Kecemasan yang terjadi pada anak dapat diatasi dengan kegiatan bermain. Kegiatan bermain digunakan peneliti sebagai media terapi untuk menurunkan kecemasan anak yang menjalani hospitalisasi. Hospitalisasi menimbulkan krisis dalam kehidupan anak dan sering disertai cemas berlebihan, maka anak-anak perlu bermain untuk mengeluarkan rasa takut dan cemas yang mereka alami sebagai alat koping dalam menghadapi cemas sehingga anak dapat tetap merasakan kesenangan dari permainan walaupun dalam keadaan sakit.

Penerapan terapi (touch and talk) telah dilakukan pada beberapa penelitian sebelumnya seperti penelitian yang dilakukan oleh Pratiwi (2016) yang menyatakan kecemasan pada anak usia pra sekolah dapat diturunkan melalui terapi touch and talk. Hasil penelitian didapatkan hasil pada kelompok eksperimen dari skor pre-test 12,00 saat post-test didapatkan skor 9,27, ada penurunan tingkat kecemasan antara sebelum dan setelah dilakukannya terapi touch and talk.

Selain permainan ular tangga kecemasan pada anak usia pra sekolah dapat diturunkan dengan melakukan permainan pasif yaitu permainan yang dilakukan tanpa mengeluarkan energi dan tidak perlu melakukan aktivitas seperti memberikan support dan sentuhan pada anak (touch and talk). Melalui terapi ini diharapkan anak mampu tertawa dan bersosialisasi pada lingkungan barunya (Yanti \& Alfathona, 2019).

Penelitian terkait yang dilakukan oleh Colin et al., (2020) dengan menerapkan terapi bermain ular tangga terhadap kecemasan pada anak usia pra sekolah yang sedang menjalani masa perawatan di ruang edelweis RSUD Dr. M. Yunus Kota Bengkulu. Hasil dari penelitian ini menunjukkan bahwa terdapat pengaruh terapi permainan ular tangga terhadap penurunan tingkat kecemasan selama menjalankan masa perawatan.

Penggunaan Alat Permainan Edukatif (APE) juga pernah diterapkan dalam penelitian oleh Yanti \& Alfathona (2019) yang menyebutkan bahwa terdapat perbedaan yang signifikan sebelum dan sesudah pemberian terapi touch and talk terhadap kecemasan anak usia pra sekolah yang dirawat di ruang rawat inap Edelweis RS. Dr. M. Yunus Bengkulu.

Berdasarkan masalah yang ditemukan penulis ingin membandingkan penggunaan Alat Permainan Edukatif (APE) dan terapi bermain ular tangga terhadap penurunan tingkat kecemasan anak (Pre School).

\section{METODE PENELITIAN}

Penelitian ini dilakukan pada anak usia pra-sekolah (4-5) tahun menggunakan rancangan quasy eksperimen dengan pretest and posttest two grup design. Intervensi diberikan pada kedua kelompok eksperimen yaitu kelompok Alat Permainan Edukatif (APE) touch and talk dan skill play bermain ular tangga.

Sampel dalam penelitian ini diambil berdasarkan kriteria inklusi, sebanyak 32 orang yang terbagi dalam dua kelompok dengan 16 orang pada kelompok Alat Permainan Edukatif (APE) touch and talk dan 16 orang pada kelompok skill play bermain ular tangga. Waktu penelitian dilakukan pada tanggal 13 Januari - 26 Februari 2020 di RS DKT Kota Bengkulu. Untuk menilai tingkat kecemasan digunakan lembar kuesioner adopsi dari lembar kuesioner HARS. 
Penelitian ini menggunakan uji t-dependent dan uji mann whitney. Uji t-dependent digunakan untuk melihat pengaruh terhadap kelompok yang datanya saling mempunyai ketergantungan saling berhubungan, sedangkan uji mann whitney digunakan untuk mengetahui perbedaan selisih median pada kedua kelompok yang berbeda.

\section{HASIL PENELITIAN Analisa Univariat}

Tabel. 1

Distribusi Frekuensi Kategori Kecemasan pada Kelompok Alat Permainan Edukatif (Ape) Touch And Talk Sebelum dan Sesudah_Diberikan Intervensi

\begin{tabular}{cccccc}
\hline \multirow{2}{*}{ No } & Kategori & \multicolumn{3}{c}{ Alat Permainan Edukatif (APE) touch and talk } \\
\cline { 2 - 5 } & & Sebelum & Persentase & Sesudah & Persentase \\
\hline 1 & Tidak Ada Kecemasan & 0 & $0 \%$ & 4 & $25 \%$ \\
2 & Kecemasan Ringan & 0 & $0 \%$ & 10 & $62,5 \%$ \\
3 & Kecemasan Sedang & 1 & $6,2 \%$ & 0 & $0 \%$ \\
4 & Kecemasan Berat & 15 & $93,8 \%$ & 2 & $12,5 \%$ \\
5 & Kecemasan Berat Sekali & 0 & $0 \%$ & 0 & $0 \%$ \\
\hline & Total & 16 & $100 \%$ & 16 & $100 \%$ \\
\hline
\end{tabular}

Berdasarkan tabel 1 diketahui bahwa sebelum dilakukan intervensi responden mengalami kategori kecemasan berat sebanyak 15 responden $(93,8 \%)$. Setelah dilakukan intervensi terjadi penurunan kategori yaitu sebagian besar menglami kecemasan ringan sebanyak 10 responden $(62,5 \%)$.

Tabel. 2

Distribusi Frekuensi Kategori Kecemasan pada Kelompok Bermain Ular Tangga Sebelum dan Sesudah Diberikan Intervensi

\begin{tabular}{lccccc}
\hline No & Kategori & \multicolumn{4}{c}{ Bermain Ular Tangga } \\
& & Sebelum & Persentase & Sesudah & Persentase \\
\hline 1 & Tidak Ada Kecemasan & 0 & $0 \%$ & 1 & $6,2 \%$ \\
2 & Kecemasan Ringan & 0 & $0 \%$ & 2 & $12,5 \%$ \\
3 & Kecemasan Sedang & 1 & $6,2 \%$ & 8 & $50 \%$ \\
4 & Kecemasan Berat & 15 & $93,8 \%$ & 5 & $31,2 \%$ \\
5 & Kecemasan Berat Sekali & 0 & $0 \%$ & 0 & $0 \%$ \\
\hline & Total & 16 & $100 \%$ & 16 & $100 \%$ \\
\hline
\end{tabular}

Berdasarkan tabel 2 diketahui bahwa sebelum dilakukan intevensi responden mengalami kategori kecemasan berat sebanyak 15 responden $(93,8 \%)$. Setelah dilakukan intervensi terjadi penurunan kategori yaitu mengalami kecemasan berat sebanyak 5 responden $(31,2 \%)$. 
Tabel. 3

Uji Normalitas (Shapiro Wilk)

\begin{tabular}{ccc}
\hline Variabel & Df & Sig \\
\hline Pre eksperimen kelompok 1 & 0,16 & 0,224 \\
Post eksperimen kelompok 1 & 0,16 & 0,065 \\
Pre eksperimen kelompok 2 & 0,16 & 0,319 \\
Post eksperimen kelompok 2 & 0,16 & 0,150 \\
\hline
\end{tabular}

Berdasarkan tabel 3 diketahui bahwa $p$-value > 0,05 yang artinya bahwa data berdistribusi normal.

\section{Analisa Bivariat}

Tabel. 4

Kategori Kecemasan pada Kelompok Alat Permainan Edukatif (APE)

Touch And Talk Sebelum dan Sesudah Diberikan Intervensi

\begin{tabular}{cccccc}
\hline Variabel & Mean & $\begin{array}{c}\text { Stand } \\
\text { Deviasi }\end{array}$ & $\begin{array}{c}\text { Stand } \\
\text { Eror }\end{array}$ & $p$ value & $\mathrm{N}$ \\
\hline $\begin{array}{c}\text { Pretest } \\
\text { Alat Permainan Edukatif (APE) } \\
\text { touch and talk } \\
\begin{array}{c}\text { Posttest } \\
\text { Alat Permainan Edukatif (APE) } \\
\text { touch and talk }\end{array}\end{array}$ & 31,62 & 2,729 & 0,682 & & 16 \\
\hline
\end{tabular}

Berdasarkan tabel 4 diketahui bahwa hasil rata-rata skor rentang kecemasan sebelum dilakukan intervensi sebesar 31,62 dan setelah dilakukan intervensi turun menjadi 17,31 dengan selisih mean sebesar 14,31 serta $p$-value 0,000 .

Tabel. 5

Kategori Kecemasan pada Kelompok Skill Play Bermain Ular Tangga

Sebelum dan Sesudah Diberikan Intervensi

\begin{tabular}{cccccc}
\hline Variabel & Mean & $\begin{array}{c}\text { Stand } \\
\text { Deviasi }\end{array}$ & $\begin{array}{c}\text { Stand } \\
\text { Eror }\end{array}$ & $p$ value & $\mathrm{N}$ \\
\hline $\begin{array}{c}\text { Pretest } \\
\text { terapi bermain ular tangga }\end{array}$ & 31,56 & 3,162 & 0,790 & & \\
$\begin{array}{c}\text { Posttest } \\
\text { terapi bermain ular tangga }\end{array}$ & 24,38 & 4,588 & 1,147 & 0,000 & 16 \\
\hline
\end{tabular}

Berdasarkan tabel 5 diketahui bahwa hasil rata-rata skor rentang kecemasan sebelum dilakukan intervensi sebesar 31,56 dan setelah dilakukan intervensi turun menjadi 24,38 dengan selisih mean sebesar 7,18 serta $p$ value 0,000 . 


\section{PEMBAHASAN}

Berdasarkan tabel 4 dari 16 orang responden pada kelompok Alat Permainan Edukatif (APE) touch and talk didapatkan bahwa nilai rata-rata skala kecemasan sebelum diberikan intervensi adalah 32,44 dan setelah diberikan intervensi adalah 17,31 dengan selisih mean sebesar 14,31 serta nilai $p$-value 0,000. Dari hasil analisis tersebut dapat disimpulkan bahwa ada perbedaan yang signifikan antara sebelum dan sesudah diberikannya intervensi terhadap kecemasan anak usia pra sekolah. APE adalah alat permainan yang dapat mengoptimalkan perkembangan anak, disesuaikan dengan usianya dan tingkat perkembangannya (Padila et al., 2019).

Hai ini sejalan dengan pendapat yang dikemukakan oleh Handajani \& Yunita (2019) bahwa terdapat beberapa cara yang efektif untuk menurunkan kecemasan anak selama hospitalisasi seperti bermain, teknik distraksi audio visual, terapi touch and talk, memberi permainan yang sesuai dengan anak usia pra sekolah seperti lilin yang dibentuk, alat-alat menggambar, puzzle sederhana, manik-manik ukuran besar, bola, gunting menggunting.

Serupa dengan Alat Permainan Edukatif (APE) touch and talk terapi bercerita juga pernah dilakukan dalam penelitian oleh Legi et al., (2019) yeng menyebutkan bahwa terapi bercerita efektif terhadap penurunan kecemasan anak usia pra sekolah yang dilakukan tindakan invasif pemasangan infus. Adanya penurunan tingkat kecemasan pada anak karena ada media sebagai pengalihan perhatian anak ketika akan dilakukan pemasangan infus. Hal tersebut terjadi karena kecemasan yang terjadi disebabkan karena otak menstimulasi saraf otonom sehingga terjadi pelepasan epinefrin oleh kelenjar adrenal akibat adanya stimulus yang menyenangkan maka endorphin akan dilepaskan sehingga dapat menghambat stimulus cemas.

Teknik terapi touch and talk merupakan suatu bentuk yang dilakukan untuk mengalihkan perasaan kecemasan menjadi rasa percaya diri pada anak agar cepat kembali beraktivitas seperti biasanya, yang dalam hal ini perawat memberikan sentuhan dan motivasi kepada anak (Pratiwi, 2016). Terapi ini dilakukan dengan memberikan sentuhan serta motivasi terhadap anak, dimana anak merasa lebih nyaman saat adanya sentuhan. Dalam pemberian terapi touch and talk peneliti memberikan respon berupa sentuhan dan motivasi dimana sentuhan motivasi itu direspon oleh indra pendengaran dan peraba dikirim melalui sistem saraf tepi yaitu sistem saraf sensori lalu dikirim ke otak dan sum-sum tulang belakang melalui sistem saraf motorik. Dalam otak yang berperan dalam merespon impuls kepercayaan diri adalah sirotonin. Kemudian akan dikirim kembali kesistem saraf tepi yaitu berupa respon kepercayaan diri (Greenstein \& Diana, 2016).

Hal ini didukung oleh pendapat yang dikemukakan oleh Padila et al., (2019) dalam penelitian yang menyebutkan bahwa, terapi dengan bercerita (story telling) merupakan salah satu teknik bermain terapeutik yang bercerita atau mendongeng dalam menyampaikan isi perasaan, buah pikiran atau sebuah cerita kepada anak-anak melalui lisan. Manfaat dari kegiatan mendongeng ini antara lain adalah mengembangkan fantasi, empati dan berbagai jenis perasaan lain, serta menumbuhkan minat baca dan mengembangkan daya sosialisasi anak, serta sarana komunikasi anak dengan orangtuanya

Berdasarkan tabel 5, dari 16 responden pada kelompok bermain ular tangga didapatkan bahwa nilai rata-rata skala kecemasan sebelum diberikan intervensi sebesar 33,38 dan setelah diberikan intervensi sebesar 24,38 dengan selisih mean sebesar 7,18 serta nilai $p$ - 
value 0,000. Dapat disimpulkan bahwa ada perbedaan yang signifikan antara sebelum dan sesudah diberikannya intervensi terhadap kecemasan anak usia pra sekolah.

Penelitian serupa pernah dilakukan oleh Colin et al., (2020) yang menyatakan bahwa dari 20 orang responden yang diberikan intervensi bermain ular tangga menunjukkan terjadi peningkatan tingkat kooperatif antara sebelum dan setelah dilakukan permainan ular tangga. Hasil tersebut menunjukkan bahwa pemberian terapi bermain ular tangga diantaranya dapat membantu anak-anak menjadi lebih bertanggung jawab atas perilaku yang dilakukannya dan mengembangkan solusi baru dan kreatif untuk masalah yang anak hadapi.

Hal ini sejalan dengan penelitian oleh Rahmawati (2020) yang menyebutkan bahwa pemberian teknik distraksi dapat meningkatkan kemampuan berkonsentrasi anak sehingga mulai berinteraksi terhadap perawat. Hal ini menunjukkan bahwa respon koping anak dalam manajemen nyeri dan tingkat kecemasan dapat diperbaiki dengan pemberian teknik distraksi.

Berdasarkan tabel 6, diketahui bahwa dari 32 orang responden yang terbagi atas 2 kelompok yaitu kelompok Alat Permainan Edukatif (APE) touch and talk dan kelompok bermain ular tangga didapatkan nilai rata-rata skor selisih sebelum dan sesudah intervensi, pada kelompok Alat Permainan Edukatif (APE) touch and talk didapatkan nilai selisih sebesar 14,31 dan pada kelompok bermain ular tangga sdidapatkan nilai selisih sebesar 7,18 dengan p-value 0,001, dan dapat disimpulkan bahwa kelompok Alat Permainan Edukatif (APE) touch and talk lebih efektif menurunkan kecemasan anak usia pra sekolah dibandingkan kelompok bermain ular tangga.

Yanti \& Alfathona (2019) pernah melakukan penelitian serupa dengan membandingkan antara terapi touch and dengan terapi bercerita. Dari hasil penelitian tersebut dapat menyatakan bahwa ada perbedaan yang signifikan antara terapi touch and talk dan terapi bercerita dan menyatakan bahwa terapi terapi touch and talk lebih efektif digunakan untuk menurunkan kecemasan anak 3-6 tahun yang mengalami hospitalisasi. Anak cendrung memberi respon yang lebih baik ketika diberikan terapi touch and talk seperti tersenyum dan tertawa.

Hal ini didukung pendapat oleh Retnani et al., (2019) dalam penelitiannya menjelaskan pemberian teknik distraksi dapat membuat anak lebih fokus pada suatu kegiatan tertentu, hal tersebut mengakibatkan impuls nyeri yang disebabkan adanya cedera tidak mengalir melalui tulang belakang, pesan nyeri tidak tersampaikan ke otak sehingga anak tidak merasakan nyeri. Berbagai persiapan guna mendukung keberhasilan tindakan tersebut adalah memperhatikan beberapa persiapan diantaranya persiapan psikologis guna mengurangi kecemasan pada anak pra sekolah, salah satunya ialah teknik non-farmakologi, seperti kehadiran orang tua, musik, akupunktur, terapi bermain, bermain dengan mainan yang sudah dikenal, dan menonton kartun dalam mengurangi tingkat kecemasan anak (Lisa et al., 2020).

Berdasarkan penelitian oleh Apriany et al., (2019) kecemasan yang dirasakan anak terjadi ketika berada di rumah sakit dan membutuhkan perawatan untuk mengatasi kecemasannya. Kecemasan yang terjadi pada anak dapat diatasi dengan kegiatan bermain. Kegiatan bermain digunakan peneliti sebagai media terapi untuk menurunkan kecemasan anak yang menjalani hospitalisasi. Hospitalisasi menimbulkan krisis dalam kehidupan anak dan sering disertai cemas berlebihan, maka anak-anak perlu bermain untuk mengeluarkan rasa takut dan cemas yang mereka alami sebagai alat koping dalam menghadapi cemas sehingga anak dapat tetap merasakan kesenangan dari permainan walaupun dalam keadaan sakit. 


\section{SIMPULAN}

Ada perbedaan antara kelompok APE touch and talk dan kelompok skill play bermain ular tangga terhadap penurunan tingkat kecemasan anak usia pra sekolah.

\section{SARAN}

Berdasarkan penelitian dan pembahasan mengenai Alat Permainan Edukatif (APE) Touch and Talk dan Skill Play terhadap penurunan skala kecemasan anak (Pre School). Penulis menyampaikan saran bagi penelitian selanjutnya diharapkan dapat mengkolaborasikan kedua terapi ini dengan terapi APE lainnya dengan berbagai tingkat usia pada rentang anak pra-sekolah.

\section{DAFTAR PUSTAKA}

Apriany, D., Oyoh, O., \& Maruf, A. F. (2018). Perbedaan Efektivitas Terapi Mewarnai dan Bermain Puzzle terhadap Kecemasan Anak Prasekolah yang Mengalami Hospitalisasi di RSUD Cibabat Kota Cimahi Tahun 2018. Prosiding PIN-LITAMAS 1, 1(1), 110121. http://repository2.stikesayani.ac.id/index.php/pinlitamas1/article/

Colin, K, B., Maydinar, D. D., \& Eka, E. (2020). Pengaruh Terapi Bermain (Skill Play) Permainan Ular Tangga terhadap Tingkat Kooperatif Selama Menjalankan Perawatan pada Anak Prasekolah (3-6 Tahun) di Ruang Edelweist Rsud Dr. M Yunus Bengkulu. Journal of Nursing and Public Health,8(1), 111-116. DOI: 10.37676/jnph.v8i1.1008

Greenstein, B., \& Diana, F. W. (2016). Ed2. Sistem Endokrin. Jakarta: Airlangga

Handajani, D. O., \& Yunita, N. (2019). Apakah Ada Pengaruh Terapi Bermain Puzzle terhadap Tingkat Kecemasan Anak Usia Prasekolah yang Mengalami Hospitalisasi di Rs Bhakti Rahayu Surabaya. Jurnal Manajemen Kesehatan Indonesia, 7(3), 198-204. DOI: 10.14710/jmki.7.3.2019.198-204

Legi, J., Sulaeman, S., \& Purwanti, N. (2019). Pengaruh Story telling dan Guided-Imagery terhadap Tingkat Perubahan Kecemasan Anak Usia Prasekolah yang Dilakukan Tindakan Invasif. Journal of Telenursing (JOTING), 1(1), 145-156. https://doi.org/https://doi.org/10.31539/joting.v1i1.496

Lisa, M., Mustika, A., \& Lathifah, N. S. (2020). Alat Permainan Edukasi (APE) Meningkatkan Perkembangan Motorik Halus pada Anak Usia 4-6 Tahun. Jurnal Kesehatan, 11(1), 125-132. DOI: 10.26630/jk.v11i1.1584

Marni, M., \& Ambarwati, R. (2019). Pengaruh Terapi Bermain Mewarnai terhadap Penurunan Kecemasan pada Anak Usia Prasekolah. Jurnal Keperawatan GSH, 7(1), 24-29. http://journal.akpergshwng.ac.id/index.php/gsh/article/view/65

Padila, P., Agusramon, A., \& Yera, Y. (2019). Terapi Story Telling dan Menonton Animasi Kartun terhadap Ansietas. Journal of Telenursing (JOTING), 1(1), 51-66. https://doi.org/https://doi.org/10.31539/joting.v1i1.514

Padila, P., Andari, F. N., Harsismanto, J., Andri, J. (2019). Tumbuh Kembang Anak Usia Toddler Berbasis Research. Lubuklinggau: ASRA

Pratiwi, N. I. (2016). Pengaruh Terapi Touch and Talk terhadap Kecemasan Anak Usia prasekolah yang mengalami tindakan invasif di RSUD Dr. Moewardi Surakarta. Universitas Muhammadiyah Surakarta 
Rahmawati, E. (2020). Terapi Musik Baby Shark Mampu Menurunkan Kecemasan pada Anak Usia Prasekolah. Journal of Telenursing (JOTING), 2(1), 1-10. https://doi.org/https://doi.org/10.31539/joting.v2i1.1098

Retnani, A., Sutini, T., \& Sulaeman, S. (2019). Video Kartun dan Video Animasi dapat Menurunkan Tingkat Kecemasan Pre Operasi pada Anak Usia Pra Sekolah. Jurnal Keperawatan Silampari,3(1), 332-341. https://doi.org/https://doi.org/ 10.31539/ jks.v3i1.837

Yanti, L., \& Alfathona, I. (2019). Efektivitas Terapi Touch And Talk dan Terapi Bercerita terhadap Kecemasan Anak Usia 3-6 Tahun di Ruang Edelweiys RSUD Dr. M. Yunus Bengkulu. Jurnal Keperawatan Muhammadiyah Bengkulu,7(1), 1-9. DOI: 10.36085/jkmu.v7i1.302 